\title{
Development Of Experiment-Based Student Worksheet In The Basic Concept Subjects Of Science 2 Pgsd FIP UNM
}

\author{
${ }^{1}$ Adnan, K, ${ }^{2}$ Muhammad Amran, ${ }^{3}$ St. Asmah \\ \{adnan@yahoo.co.id ${ }^{1}$, neysamran@gmail. Com ${ }^{2}$, St.asmah@unm.ac.id ${ }^{3}$ \} \\ ${ }^{1,2,3}$ Faculty of Education, Makassar State University, Indonesia
}

\begin{abstract}
This study aims to develop an experiment-based student worksheet in the basic concept subjects of Sciences 2 in the Basic Concepts of Sciences 2 PGSD FIP UNM. The lecturers' findings show that when carrying out student practicum activities they still do not vary much in the use of student worksheets. This research was conducted on the fourth semester students who took the basic science 2 courses with a total of 20 people. The results showed that the development of project-based science learning tools based on the response of lecturers and students was in the very good category. The results of the validation carried out by an expert team on the Project-based science learning tools are in very good category. Thus, it can be concluded that the development of student worksheets based on experiments is very good and suitable for use in the lecturing process of the basic concepts of Sciences 2 when carrying out practical activities in the laboratory.
\end{abstract}

Keywords: Student Worksheet, Experiment Method.

\section{Preliminary}

The World of Education Indonesia has succeeded in making various progress, especially in providing opportunities to obtain the same education to all citizens. This success is not in accordance with improving the quality of education. This can be seen from the still low quality of education in Indonesia.

Humans as social creatures need education to answer the challenges of the times and increasingly rapid technological progress. In the 1945 Constitution stipulates that; the right of citizens to receive teaching (education) and the government must implement a national teaching system. To be able to equip themselves with a variety of basic skills, therefore a formal education institution is needed, one of which is a higher education institution that is held to develop attitudes and abilities of knowledge and skills in order to face the era of globalization.

One of the problems in developing knowledge and understanding of scientific concepts (Science) for students lies in the lecture process or learning experience. The lecture process that is obtained in class is not complete and is not oriented to achieving basic competency and potential standards. Learning is more teacher-centered or traditional Learning. Furthermore, the problem that also arises is that students sometimes experience boredom in attending lectures. to develop the potential of thinking, the lecture process is always required to be more varied and practical.

To overcome the problem of special education in higher education institutions, some abilities are also needed by students, namely the ability to create communicative situations and 
enable students to convey and receive authentic messages that contain interesting information and prepare students to be able to think logically, critically, creative and can argue properly. In addition, students also need the ability to ask questions, find answers, understand answers and refine answers. This ability can be obtained in the basic concepts of Science 2 if the lecture process is carried out on an experimental basis. With the experimental method, students have more opportunities to involve curiosity on the object being studied, expressing curiosity through questions taught by students and teachers and provide a means of playing for students through exploration and investigation activities so that in the learning process students are required to ask questions and find answers to questions themselves. Thus, it allows learning activities and learning outcomes to be more meaningful.

To realize the above, one of the efforts that can be done is to prepare student worksheets well and on target that are integrated with experiment based. The resulting worksheets are in accordance with the material discussed in the basic concept subjects of science 2 PGSD FIP UNM.

The experimental method is a way of presenting subject matter where students conduct experiments by experiencing to prove themselves questions or hypotheses being learned. The experimental method is a way of teaching, where students conduct an experiment about something, observe the process and write down the results of the experiment, then the results of the observations are conveyed to the class and evaluated by the experimental method is a way of presenting subject matter where students conduct experiments by experiencing to prove themselves something questions or hypotheses that are learned. The experimental method is a way of teaching, where students conduct an experiment about something, observe the process and write down the results of the experiment, then the results of the observations are conveyed to the class and evaluated by the teacher.

The use of this technique has the aim so that students are able to find and find their own answers or problems faced by conducting their own experiments. Also students can be trained in scientific thinking. By experimentation students find proof of truth from the theory of something they are learning. In the learning process using the experimental method students are given the opportunity to experience themselves or do it themselves, follow a process, observe an object, analyze, prove and draw their own conclusions about an object of a particular state or process. From the description above, it appears that the experimental method is different from the demonstration method. If the demonstration method only emphasizes the process of occurrence and ignores the results, while in the experimental method the emphasis is on the process to the results. Experiments or experiments conducted do not always have to be carried out in a laboratory but can be done in the natural environment.

\subsection{Strengths of the Experiment Method}

a. This method can make students more confident in the truth or conclusions based on their own experiments rather than just accepting the teacher's words or books.

b. Students can develop attitudes to conduct exploratory studies (explore) about science and technology.

c. With this method humans will be built that can bring new breakthroughs with discovery.

d. Students gain experience and skills in conducting experiments.

e. Students are actively involved in gathering facts and information needed for the experiment. Can use and implement scientific method procedures and scientific thinking

f. Can enrich students' experiences and thinking with things that are objective, reality and eliminate verbalism. 


\subsection{Weaknesses of the Experiment methods}

a. Inadequate tools cause not every student has the opportunity to conduct experiments.

b. If the experiment requires a long period of time, students must wait to continue the lesson.

c. Errors and failures of students that are not detected by the teacher.

d. Often have difficulty in carrying out experiments because teachers and students lack experience in conducting experiments.

e. Errors and failures of students that are not detected by the teacher in experimenting result in students making mistakes.

In order to use the experimental method efficiently and effectively, the following matters need to be considered:

1) In an experiment each student must conduct an experiment, then the number of tools and materials or experimental material must be sufficient for each student.

2) So that the experiment does not fail and students find convincing evidence, or maybe the results are not harmful, then the condition of the equipment and the quality of the experimental material used must be good and clean.

3 in experiments students need to be careful and concentrated in observing the process of the experiment, it is necessary to have a long time, so they find proof of the truth of the theory being studied.

4) Students in experiments are learning and practicing, so they need to be given clear instructions, because in addition to gaining knowledge, experience and skills, also the maturity of the soul and attitude need to be taken into account by the teacher in choosing the object of the experiment.

Not all problems can be experimented, such as psychological issues, some aspects of social life and human beliefs. Another possibility is because the tool is very limited, so the problem cannot be held experimentally because the tool does not yet exist.

\subsection{Experimental procedure}

a. It needs to be explained to students about the purpose of the experiment, they must understand the problem that will be proven through the experiment.

b. Give an explanation to students about the tools and materials that will be used in the experiment, things that must be controlled strictly, the order of experiments, things that need to be noted.

c. During the experiment the teacher must oversee the work of students. If you need to provide suggestions or questions that support the perfection of the experiment.

d. After the experiment is finished the teacher must collect the results of student research, discuss in class, and evaluate with tests or questions and answers.

In the experimental method, the teacher can develop physical and mental involvement, as well as emotional students. Students have the opportunity to practice process skills in order to obtain maximum learning outcomes. Experiences that are experienced directly can be embedded in his memory. It is hoped that the physical and mental as well as emotional involvement of students can be introduced to a way or condition of learning that can foster self-confidence and also innovative and creative behavior. Learning by the experimental method trains and teaches students to learn physics concepts as well as a physics scientist. 
Students learn actively by following the stages of learning. Thus, students will find their own concepts in accordance with the results obtained during learning.

\subsection{Experimental Stage}

Learning by the experimental method includes the following stages:

a) Initial Experiments, Learning begins with conducting experiments demonstrated by the teacher or by observing natural phenomena. This demonstration presents problems related to the physical material to be studied.

b) Observation is a student's activity when the teacher conducts an experiment. Students are expected to observe and record the event.

c) Initial hypothesis, students can formulate a temporary hypothesis based on the results of their observations.

d) Verification, activities to prove the truth of the initial allegations that have been formulated and carried out through group work. Students are expected to formulate the results of the experiment and make conclusions, then the results can be reported. Application concepts, after students formulate and discover concepts, the results are applied in their lives. This activity is a stabilization of the concepts that have been learned.

e) Evaluation, is the final activity after finishing one concept.

Application of learning with experimental methods will help students to understand concepts. Understanding the concept can be known if students are able to express verbally, in writing, and applications in their lives. In other words, students have the ability to explain, mention, give examples, and apply concepts related to the subject.

\section{Research Methods}

This research is a research development by following the stages of the implementation of this research following the stages of the development of the ADDIE model which consists of five stages namely Analyze, Design, Development, Implementation, and Evaluation. ADDIE development model is an easy-to-apply model, where the process used is systematic with a clear framework, produces creative, and efficient products.

The location of this study is the PGSD Study Program by involving PGSD UNM Makassar students who took the Basic Concept of Science 2 course in the even semester of 2017-2018.

Data / information collection techniques from student worksheets developed were observation, interviews and questionnaires. Observation is used directly by researchers to see and examine all the phenomena that exist, about the response of participants to student worksheets that are developed. Interviews were conducted to complete the information / data obtained through a questionnaire filled out by the assessor in this case the validator. Furthermore, the questionnaire was used to screen the validation data of student worksheets and the validation of science experts, the evaluation questionnaire for small group trials and field trials. Basically the questionnaire encompasses user responses regarding products developed by looking at aspects of student worksheets. In addition, user responses regarding the practicality of the product being developed.

The data analysis technique in this research is descriptive analysis, which describes the results of development and, the validator's response, the results of small group trials, and the results of field trials. Because this study uses a small sample and is not chosen randomly, the data analysis uses non-parametric statistics. Nonparametric analysis is also used according to 
the type of data and analysis objectives to be achieved. This type of data analysis is described in more detail to answer each research question as follows:

\section{Validity Data Analysis}

Data of expert validity results were analyzed by considering input, comments, and suggestions from the validator. The results of the analysis serve as a guideline for revising the student worksheets developed. The activities carried out in the process of validating data analysis are student worksheets which include validation sheets for content experts for students and science experts. The validity categories for each aspect or all aspects assessed are applied based on the criteria for categorizing the quality of student worksheets presented in Table 3.1.

Table 3.1 Validity Categories of Assessment Aspects

\begin{tabular}{lll}
\hline No. & Interval & Category \\
\hline 1 & $4,6 \leq \mathrm{M}<5,0$ & Very Valid \\
\hline 2 & $3,6 \leq \mathrm{M}<4,5$ & Valid \\
\hline 3 & $2,6 \leq \mathrm{M}<3,5$ & Quite valid \\
\hline 4 & $1,6 \leq \mathrm{M}<2,5$ & Less Valid \\
\hline 5 & $0,0 \leq \mathrm{M}<1,5$ & Invalid \\
\hline
\end{tabular}

Source: Saifuddin (2012)

Note: $\mathrm{M}=$ average score for each aspect assessed

Based on Table 3.1, the criteria used to assess student worksheet products at an adequate degree of validity are if the average (M) assessment results for all aspects are at least in the "valid" category. If the level of achievement of validity is below valid, a revision is needed based on the correlation of the validator and the response of lecturers and students.

\section{User Responses / Lecturer and Student Responses}

Data obtained from the distribution of questionnaires / questionnaires were analyzed by determining the number of lecturers and students who gave answers valued positive and negative responses for each category asked in the questionnaire. To analyze the responses of lecturers and students to aspects of content, language and presentation quality. from the device used categorization which is calculated based on the normal curve with the criteria as described in Table 3.2.

Table 3.2 Categories of User Responses of lecturers and students

\begin{tabular}{lll}
\hline No. & Interval & Category \\
\hline 1 & $0,0 \leq \mathrm{M}<1,5$ & Not Good \\
\hline 2 & $1,6 \leq \mathrm{M}<2,5$ & Less Good \\
\hline 3 & $2,6 \leq \mathrm{M}<3,5$ & Quite Good \\
\hline 4 & $3,6 \leq \mathrm{M}<4,5$ & Good \\
\hline 5 & $4,6 \leq \mathrm{M}<5,0$ & Very Good \\
\hline
\end{tabular}


Source: Saifuddin (2012)

Note: $\mathrm{M}=$ average score for each aspect assessed

Based on Table 3.2 shows that the criteria used to assess project-based student worksheet products is when the average lecturer and student (M) responds in the positive / good category to every aspect in question. If the response of lecturers and students under the category of positive / high, it is necessary to revise based on the value of each indicator and comments provided. Then it will be carried out in the next trial until an ideal project-based science learning device product is obtained.

Research Target Year I: (1) LKM (Student worksheet) for the basic concept of Science 2 based on Experiments, (2) as a speaker at national seminars and (3) Publication of scientific articles in national journals. Research Target Year II: (1) Experimental-based learning models, (2) Publication of scientific articles in national journals or international journals.

Indicators of achievement of this study are; (1) experimental-based worksheet as a guideline in the implementation of practicum for the basic concepts of sciences 2 , (2) students' motivation to learn will increase and lecturers apply the experiment-based lecture process in courses on the basic concepts of science 2 .

\section{Results and Discussion}

The approach method used in this research is research and development to produce worksheets for students of the basic concepts of Science 2 even semester for Academic Year 2017-2018. To facilitate development, researchers need to consider the LKM (student worksheet) tools that are available with the product to be developed. This is intended to make the physical form of the design more complete and in accordance with the material that will be presented in the student worksheet development plan.

\section{Stages of Development of Student Worksheets}

The development model used in this study is the ADDIE model which consists of five stages, namely Analyze, Design, Development, Implementation, and Evaluation. As for the reason the researchers took this development model because the ADDIE development model is because the ADDIE model is an easy to apply model, where the process used is systematic with a clear framework, produces effective, creative, and efficient products.

a. The Analyzing Stage

Basically, the analysis phase of the research development procedure is the analysis of the needs of the lecturers and students. Therefore, the first level of this development model is to conduct a needs analysis. At this stage, gathering information on how learning tools are developed according to the needs and desires of users. Observations were made to obtain various kinds of information about the development of learning tools developed so far. The development of student worksheets is expected to be a reference for lecturers who are in charge of the course in the implementation of practicum courses for basic science concepts.

Analysis of the need for procedural models is described at the beginning of the development, which is located at the first level. This position gives the meaning of needs analysis conducted on the user side, both at the lecturer level, and at the level of students (as users), which aims to find out issues related to this research. 


\section{b. Design Stage}

The design phase is carried out with the following terms of reference: (a) for whom are the student worksheet sets designed? (b) how to determine the design of student worksheets.

\section{c. Development Stage}

Efforts were made to obtain the results of research on the development of student worksheets in the subject matter of the basic concepts of Sciences 2 as expected, then the validity and practicality tests were carried out. The results of expert validity were analyzed by considering input, comments, and suggestions from the validator. The results of the analysis serve as a guideline for revising the student worksheets developed. The activities carried out in the process of data analysis are validity of learning devices which include validation sheets for content experts / learning device content.

\section{d. Implementation Stage}

At this stage the learning device is tested. The learning device test is carried out to obtain data about the response of lecturers and students to the worksheet of students of the sciences 2 . This stage will be taken in 2 steps including: a small group trial, and a field trial.

1) Small Group Trial

The small group trial implementation involved 2 lecturers and 3 students. The aspects that are evaluated by lecturers and students are aspects of language content and presentation quality of student worksheets.

Description of Lecturer Response results about aspects of content / content on student worksheets includes 3 components / indicators namely the quality of the preparation of student worksheets, the quality of language and the accuracy of the questions. The average lecturer response to aspects of content, language and quality of presentation of student worksheets is presented in Table 5.1.

Table 5.1. Lecturer Responses to the Content, Language and Quality Aspects of Student Worksheet Presentations on Small Group Trials

\begin{tabular}{clcl}
\hline $\begin{array}{c}\mathrm{N} \\
\mathrm{o}\end{array}$ & Components / indicators & $\bar{x}$ & $\begin{array}{l}\text { Informati } \\
\text { on }\end{array}$ \\
\hline 1. & $\begin{array}{l}\text { Systematic quality of } \\
\text { student worksheet }\end{array}$ & 4,6 & $\begin{array}{l}\text { Very } \\
\text { good }\end{array}$ \\
\hline 2. & Language quality & 4,7 & $\begin{array}{l}\text { Very } \\
\text { good }\end{array}$ \\
\hline 3. & Presentation Quality & 4,7 & $\begin{array}{l}\text { Very } \\
\text { good }\end{array}$ \\
\hline
\end{tabular}

Source: Results of Analysis of Lecturer Responses to Content, Language and Quality of Small Group Trial Presentation

Based on Table 5.1 shows that the average response of lecturers to the aspects of Content, Language and Presentation Quality in small group trials on the quality components / indicators of the preparation of learning tools is 4.6, on the components / indicators of language quality that is 4.7 and on the components / indicators the accuracy of the questions is 4.7, overall the Lecturers' responses to the aspects of content, Language and Presentation Quality are in the very good category. 
Students response about aspects of Content, Language and Quality of Presentation in the learning device includes 3 components / indicators, namely the systematic quality of device preparation, language quality and accuracy of the questions. Average student responses to aspects of content, Language and Presentation Quality are presented in Table 5.2.

Table 5.2. Student Responses to the Content, Language and Presentation Quality of Learning Tools on Small Group Trials

\begin{tabular}{clcl}
\hline No & \multicolumn{1}{c}{$\begin{array}{c}\text { Components / } \\
\text { indicators }\end{array}$} & $\bar{x}$ & Information \\
\hline \multirow{2}{*}{ 1. } & Systematic quality of & 4, & \multirow{2}{*}{ Very good } \\
& device & 8 & \\
\hline \multirow{2}{*}{2.} & Language quality & 4, & Very good \\
\hline \multirow{2}{*}{3.} & \multirow{2}{*}{ Presentation Quality } & 4, & Very good \\
\hline
\end{tabular}

Source: Results of Analysis of the Student's Response to the Content, Language and Quality of Small Group Trial Presentations.

Based on Table 5.2 shows that the average student response to aspects of content, Language and Presentation Quality of Learning Devices in small group trials on the evaluation material quality component is 4.8 , on the language quality component that is 4.9 and on the accuracy component is 4,8 overall the response of students on aspects of content, Language and Presentation Quality are in the very good category.

\section{2) Field Test}

Field trials are carried out on 20 students. As with previous trials, each subject will give a response to the aspects of Content, Language and Presentation Quality of the developed science learning equipment.

Student Response to the aspects of Content, Language and Quality of Presentation Student worksheets in field trials include three components / indicators namely the quality of the systematics, the quality of the language and the accuracy of the questions. Each trial will give a response after participating in the trial. Average student responses are presented in Table 5.3.

Table 5.3. Student's Response to the Content, Language and Presentation Quality of Science Learning Tools in Field Trials

\begin{tabular}{clcc}
\hline No & $\begin{array}{l}\text { Components } / \\
\text { indicators }\end{array}$ & $\bar{x}$ & Information \\
\hline 1. & $\begin{array}{l}\text { Evaluation } \\
\text { material quality }\end{array}$ & 5,0 & Very good \\
\hline 2. & $\begin{array}{l}\text { Language } \\
\text { quality }\end{array}$ & 4,8 & Very good \\
\hline 3. & $\begin{array}{l}\text { Accuracy of } \\
\text { problems }\end{array}$ & 4,8 & Very good \\
\hline
\end{tabular}


Source: Results of Analysis of Student Responses to the Content aspects, Language and Quality of Field Trial Presentations

Based on Table 5.3 shows that the response of students in field trials to aspects of Content, Language and Quality of Presentation of science learning equipment on the component quality of evaluation material is 5.0 on the component of language quality is 4.8 and on the component accuracy is about 4.8 with the overall category is very good.

\section{Validity and Practical Testing of Student Worksheets}

a. Validity Test

Validation conducted by researchers aims to determine whether the science learning tools that have been made can be used appropriately in trials. Learning tools in the basic science concepts courses before being used in lecturing activities must have valid qualifications. Ideally, a developer needs to re-examine the experts (validator) regarding the accuracy of the content, learning material, compliance with learning objectives, and physical design. to get a good rating by the validator.

The validation process is expected to provide a valid or very valid assessment on the design of the development of science learning tools so that it can be used for the lecture process. If the evaluation of the learning tool developed is not yet valid, then validation will continue until a valid assessment is obtained.

The validation series process in this study was carried out simultaneously with validators who had recommendations, were competent and understood about the contents and appearance of the products produced and were able to provide input / suggestions to improve the design of the science learning tools that had been designed. Suggestions from the validator will be used as material to revise the science learning tools that are being developed. The science learning tools made by the researcher were validated by experts consisting of 2 (two) PGSD FIP lecturers at Makassar State University.

1) Research Instrument Validation

The research instrument is a measuring instrument in research. A valid instrument means the research measuring instrument used is valid (can measure correctly and properly). Validation of research instruments is the level of accuracy and accuracy of a research instrument in measuring. A valid instrument is a requirement to obtain valid research results. The results of the validator's assessment of the research instruments used in this study are presented in Table 5.4.

Table 5.4. Expert Instrument Validation Results of Content / Language Instruments, Presentation Quality

\begin{tabular}{clcc}
\hline No & \multicolumn{1}{c}{$\begin{array}{c}\text { Aspect of } \\
\text { Assessment }\end{array}$} & $\bar{x}$ & Remarks \\
\hline 1 & $\begin{array}{l}\text { Aspect of } \\
\text { instructions }\end{array}$ & 4,5 & Valid \\
\hline 2 & $\begin{array}{l}\text { Aspect of } \\
\text { coverage }\end{array}$ & 4,6 & Very Valid \\
\hline 3 & $\begin{array}{l}\text { Aspects of } \\
\text { language }\end{array}$ & 4,34 & Valid \\
\hline
\end{tabular}


Source: The results of the validation of the expert instrument sheet of content, Language and Presentation Quality

Based on Table 5.4 above shows below the results of the validation of the expert instrument of content, Language and Presentation Quality on the aspect of instructions shows an average of 4.5 with very valid information, on the aspect of coverage shows an average of 4.6 with very valid information and on aspects of language show an average of 4.34 with valid information. In general, the validator's assessment of the content expert instruments, Language and Presentation Quality are in the category of very valid with information can be used with minor revisions.

\section{2) Media Validation}

Student worksheets are declared valid if the results of the assessment of the validator $3 \leq$ RTV $<4$. The results of the validity test on the development of the student worksheets for the basic concept courses of Sciences 2 which have been assessed by the validator are presented as follows:

Expert validators of content, Language and Presentation Quality in particular validate aspects of Content, Language and Quality of Presentation of student worksheets that include three aspects namely the systematic quality of the device, the quality of the language and the accuracy of the questions. The average results of the validator's assessment of the content of the project-based science learning tools are presented in Table 5.5.

Table. 5.5. Expert Validation Results of Content, Language and Quality of Presentation Evaluation Tool

\begin{tabular}{clcc}
\hline No & $\begin{array}{c}\text { Aspect of } \\
\text { Assessment }\end{array}$ & $\bar{x}$ & Remarks \\
\hline 1. & $\begin{array}{l}\text { Systematic } \\
\text { quality of the } \\
\text { device }\end{array}$ & 4,7 & VeryValid \\
\hline 2. & $\begin{array}{l}\text { Language } \\
\text { quality }\end{array}$ & 4.6 & Very Valid \\
\hline 3. & $\begin{array}{l}\text { Quality of } \\
\text { Presentation }\end{array}$ & 4,5 & Valid \\
\hline
\end{tabular}

Source: Expert Validation Results of Content, Language and Presentation Quality

Based on Table 5.5 shows that the average validator's assessment of the Content, Language and Presentation Quality from the aspect of evaluation material quality is 4.7, assessment of the language quality aspect is 4.6 and the assessment of the accuracy of the questions is 4.5 .

\section{b. Practicality Test}

Student worksheets are said to be practical if the validator states that the student worksheets are appropriate to be used without revisions or slight revisions. The revised design of student worksheets was carried out based on the suggestions given by the validator at the time the validation was carried out so as to produce a decent student worksheet in the learning process. Based on the results of the assessment of the two validators in general on student worksheets shows that the student worksheets are worthy of use with a little revision, this 
shows that the student worksheets meet practical criteria as explained in Chapter III about the criteria for evaluation tools developed said to be practical.

\section{Discussion}

Research on the development of student worksheets, using the type of research and development research using the ADDIE development model that aims to produce student worksheets that meet the validity and practical requirements.

\section{Stages of Development of Learning Devices}

The process of developing student worksheets in the based concept subject of the science 2 on the use of the project is carried out in 5 stages, namely: analyze, design, development, implementation and evaluation. The stages of the development process are described as follows.

\section{a. Analyze Stage}

Development begins with a problem in the previous student worksheet. After analyzing the problem of the need to develop new learning tools by using used materials, the researcher also analyzed the feasibility and requirements for developing the new student worksheet. At this stage identification of estimated needs is carried out, studying the literature and researching on a small scale to formulate a research framework. This stage begins with a literature study and literature study to analyze the needs of lecturers and students in the lecture process in the basic concept subjects of science 2 both in terms of facilities and infrastructure for the implementation of learning. This stage is the basis for making plans for developing student worksheets.

\section{b. Design Stage}

The design phase is a systematic process of developing science students worksheets starting with the design of RPS and LKM by determining the subject matter to be developed based on the PGSD FIP UNM curriculum. Furthermore, the RPS and LKM that have been made are systematically improved in writing and appearance.

\section{c. Development Stage}

Activities carried out at this stage also consist of expert validation. This is done to determine whether the instruments that have been made are valid. The results of both validators for media expert instruments and material experts are very valid despite minor revisions related to writing techniques. Product testing or modeling is a very important part of development research, which is carried out after product design is complete. Product testing aims to see to what extent products that are made reach the goals or objectives and know the products made have been used or not. A good product if it meets two criteria, namely the function criteria or product content (Instructional criteria) and display criteria (Presentation criteria).

\section{d. Implementation Stage}

This stage conveys student worksheets with 3 test phases that have been carried out, the small group trial phase shows that the student worksheets are already made well but still needs a little revision in the aspect of content then continued. After that, it was continued with field trials involving 20 research subjects with the results of the development showing that the 
student worksheets were already very good and could be used in the lecture process in the basic concepts of Science 2 .

\section{e. Evaluation stage}

At this stage an evaluation is carried out whether the student worksheets are in accordance with predetermined objectives. The data obtained in the trial is analyzed, developed and made necessary improvements. Then after that the product finalization stage is carried out, the final stage of a student worksheet product design.

\section{Results of Validation and Practicality Tests for Student Worksheets}

Based on the results of the assessment of the two validators, it shows that the results of the student worksheets on content validation developed are in a valid category and are worth testing with minor revisions. Therefore, revisions were made based on the experts' recommendations before further development trials were carried out. The results of expert validation on the content based on the response of the Lecturer and Student as a whole meet the valid and practical criteria to be applied.

In general, the trial results have met the practical requirements based on a general assessment of all components that have been validated by experts in general, all validators provide that the assessed components can be used with minor revisions. The observations of two observers on the project-based student worksheets were said to be adequate because all the components that were assessed in the instrument were carried out with a high level of reliability, so the student worksheets that were developed met the practicality criteria.

\section{Strengths and Weaknesses of Student worksheet.}

After testing a student work sheet on a basic concept course of Science 2 can be described several strengths and weaknesses.

Strengths of student worksheets:

1. Very good because materials used are very easy to get and according to RPS.

2. Students can directly conduct practicum activities based on the LKM that has been prepared.

3. Can have a positive impact on students or the development of one's personality.

4. Facilitate lecturers and students for practicum because they are not fixated on laboratory equipment but students can creatively utilize tools and projects in accordance with those around them.

5. Making the learning atmosphere enjoyable, so students and educators enjoy the learning process.

Weaknesses of science learning tools:

1. Lecturers must carefully analyze the right material to use in practical activities

2. Students must need a longer time in the LKM process as a tool for practicum activities.

\section{Conclusion}

Based on the results of research and discussion, it can be concluded as follows:

1. Developing experimental worksheets in the very good category 
2. The level of effectiveness of the use of student worksheets is very good based on the response of lecturers and students.

forward:

Based on the research results and conclusions, the following suggestions can be put

1. It is better for the lecturer who has the effect on the basic concept of Science 2 to identify the material well in practicum activities by always developing LKM in accordance with the needs of students.

2. For the Institute, it should be facilitated by lecturers to make workshops for developing Student worksheets

\section{Reference}

Darmodjo Hendro, Jenny R.E Kaligis. 1991. Pendidikan IPA II. Jakarta: Depdikbud.

Depdiknas, 1996. Pendidikan IPA . Jakarta: Dikti

Komara, Endang. 2014. Belajar dan Pembelajaran INTERAKTIF. Bandung: PT Refika Aditama

Muijs Daniel, David Reynold. 2008. Effective Teaching Evidence and Practic. London: Sage Publications.

http://eferoniwaruwu.blogspot.co.id/2015/05/pengertian-perangkat-pembelajaran.htmldiakses pada tanggal 8 Maret 2017 pukul 09.56

Samatowa Usman, 2006. Bagaimana Pembelajaran IPA di SD. Jakarta: Direktorat Dikti dan Direktorat Ketenagaan

Sayiful Sagala 2005.Konsep dan Makna Pembelajaran: Untuk Membantu Memecahkan Problematika Belajar dan Mengajar. Bandung: CV. Afabeta.

Soedijarto. 2008. Landasan Dan Arah Pendidikan Nasional Kita. Jakarta: PT Gramedia.

Samatowa Usman, 2006. How is Natural Science Learning in Elementary School. Jakarta: Directorate of Higher Education and Directorate of Labor

Sayiful Sagala 2005. Concepts and Meanings of Learning: To Help Solve Learning and Teaching Problems. Bandung: CV. Afabeta.

Soedijarto. 2008. The Foundation and Direction of Our National Education. Jakarta: PT Gramedia. 